\title{
THE RELATIONSHIP BETWEEN INNOVATIVENESS AND EXPORT IN CROATIAN COMPANIES
}

\author{
Helena Šlogar ${ }^{1} \&$ Heri Bezić ${ }^{2}$
}

UDC / UDK: 001.895:334.72:339.564(497.5)

JEL classification / JEL klasifikacija: O3, P45

DOI: https://doi.org/10.22598/pi-be/2019.13.2.11

Original scientific paper / Izvorni znanstveni rad

Received / Primljeno: April 30, 2019 / 30. travnja 2019.

Accepted for publishing / Prihvaćeno za tisak: October 6, 2019 / 9. listopada 2019.

\section{Summary}

The purpose of this paper is to examine the relationship between innovativeness and export in Croatian companies. The study involved 303 Croatian export companies from the manufacturing industry and the information and communication technology sector. The survey was conducted using the survey method over the last three months of 2016. For this purpose, Spearman rank correlation, the Kruskal-Wallis ANOVA test and canonical analysis were used. The results show that there is a positive relationship between innovativeness and export in Croatian companies. The results offer theoretical and managerial implications. This research has practical implications for Croatian companies to increase their efficiency and innovativeness. Value is reflected in the relationship between innovativeness and export and there is an important research gap in the literature on international trade, entrepreneurship and management. In the context of this research, it is likely that innovativeness influences a company's export activities, which can be positively reflected in creating and maintaining their competitive advantage on the international market.

Keywords: innovativeness, product innovation, process innovativeness, business system innovativeness, export, Croatian companies

\footnotetext{
${ }^{1}$ Helena Šlogar, PhD, Assistant Professor, Libertas International University, Trg J.F. Kennedy 6b, Zagreb, Republic of Croatia, E-mail: hslogar@libertas.hr

${ }^{2}$ Heri Bezić, PhD, Full Professor, University of Rijeka, Faculty of Economics, Ivana Filipovića 4, Rijeka, Republic of Croatia, E-mail: heri.bezic@efri.hr
} 


\section{INTRODUCTION}

Business innovation plays an important role in explaining the differences in export activities and the success of a company. These are the main implications of the economic theory of international trade flows and the results of analysis of most of the export business innovation at the company level (Wakelin, 1998; Günther and Norbert, 1999). Export is considered to be one of the dimensions of a country's economic growth, the success of which depends on each company achieving its goals through exporting products or services. It is assumed that companies that base their development on innovativeness are preconditioned to have higher exports than non-innovative companies. The aim of this research is to determine whether there is a positive relationship between the innovativeness and export of Croatian companies.

The research question to be answered is: What is the relationship between innovativeness and export at the company level. The review of the existing literature shows that export greatly depends on innovativeness and affects the specific orientation of the company, and thus the performance of the export-oriented companies in the international market which tends to increase their competitive advantage. The paper analyses the relationship between Croatian companies' innovativeness and export for 2014 and 2015. This would enable companies in the Republic of Croatia to use the research findings to improve their business and increase exports. Furthermore, an overview of empirical research on the relationship between innovativeness and export is given. The hypothesis is followed by a description of the method and the results of the research are then given. Finally, a conclusion leading to the theoretical and practical implications of the research is presented.

\section{LITERATURE REVIEW}

\subsection{The importance of innovativeness in companies}

In a turbulent and dynamic business environment, companies compete through their day-to-day activities to build market positions and gain competitive advantage. Globalization has greatly contributed to this, along with rapid changes and rapid development of new technologies. Innovation, ability to adapt quickly, efficiency, and emphasis on the applicability of acquired knowledge, measurability of results, competitiveness and the imperative of success are just some of the attributes of modern business. The notion of innovativeness in scientific literature has been discussed with great interest (Schumpeter, 1934; Atkinson and Ezzel, 2014). A key component to companies' success is the scope of their innovativeness. Innovativeness is associated with 
the ability to introduce new ideas, products and processes into the company. This ability to innovate is one of the most important factors that affect business success (Hult et al., 2004). Innovativeness can be present in the company in the sense of readiness to try a new product line or form of advertising, or to modify existing products. Hurley and Hult (1998) point out that innovativeness is an aspect of a company's corporate culture and openness to new ideas.

Innovativeness can be defined as the ability to introduce new processes, products and/or ideas into the organization (Hurley and Hult, 1998). Innovativeness is associated with the ability to introduce new ideas, products and processes into the company (Hult et al., 2004). In this research, innovativeness is defined as a company's propensity to create and/or adopt new products and business systems (Nybakk, 2012. p. 4). Product innovation includes the development of new products, improvements to existing products and the adoption of products. Furthermore, innovation is widely recognised as an important factor for manufacturing firms (Nybakk, 2012, p. 5). Process innovativeness is defined as an action that leads to process innovation as well as the process itself (i.e. technologies and improvements used in production) that constitutes the innovation (Nybakk, 2012, p. 5). Business system innovativeness can apply to every aspect of the firm necessary to manage, structure, operate and administer the business and its internal and external environments (Nybakk, 2012, p. 5). According to Hult et al. (2004), the key component in the success of industrial firms is the extent of their innovativeness. Innovation is very important for small businesses with limited resources (Van de Vrande et al., 2009). Hoq and Che Ha (2009) confirm that innovativeness is the main mediator in the network of relationships between organizational orientation and business performance. The literature also suggests that companies need to be innovative to gain competitive advantage in order to survive (Calantone et al., 2002), i.e. innovativeness has become a prerequisite in ensuring competitive advantage. It is found that the entrepreneurial orientation and innovativeness had direct effect on the export performances of Thai small and medium enterprises (SMEs). The results showed that the entrepreneurial oriental and innovativeness had direct relationship with the variance of the export performance (Ruepitiviriya and Puttawong, 2018). In this paper, the relationship between five dimensions of entrepreneurial orientation (innovativeness, proactivity, risk taking, autonomy and competitiveness) and business performance is studied. The research was conducted in 2017 in Croatian companies. The results have shown that there is a positive and statistically significant correlation between innovativeness, proactivity and competitiveness on one side and company's business performance on the other (Šlogar et al., 2018). 


\subsection{Innovativeness and export}

States export to achieve the goals of the economic development policy, provide funds for the payment of import needs and to achieve the overall business goals (Šlogar, 2018). The Republic of Croatia with 4.3 million inhabitants (about $0.06 \%$ of the world population) is dependent on the international environment and economic conditions in the world market (Šlogar, 2018). Under such conditions, the demanding and complex business environment of investing in innovative products and strengthening of export activities are considered important factors for increasing efficiency, growth of employment and competitiveness of companies (Šlogar, 2018). Companies that want to export encounter factors that stimulate or prevent company's export activities in the market. These forces are part of the external factors related to the company's competitive environment and internal factors related to the attitude of the administration towards exports (Lazibat and Kolaković, 2004, 115). Hirsch and Bijaoui (1985) found that innovation in the company positively impacts export. Opening up foreign markets enables increased profits as a result of the company's innovation activity (Šlogar, 2018).

Taking into account the indicator of economy's openness (the share of export and import of goods and services in GDP), see Table 1, the Republic of Croatia is among the very open economies with an average of $85.1 \%$ in the observed period from 2007 to 2016. Over the past seven years, this share has grown steadily, and in 2016 it was as high as $96.4 \%$. However, the ratio of Croatian export and import and Gross Domestic Product (average 41.9\% : 43.1\%) does call for improvement. Since 2012, a positive trend was observed, meaning that the share of export in GDP was higher than the share of import. The lowest shares of export and import in GDP were reported in the crisis years of 2008, 2009 and 2010 (Šlogar, 2018). 


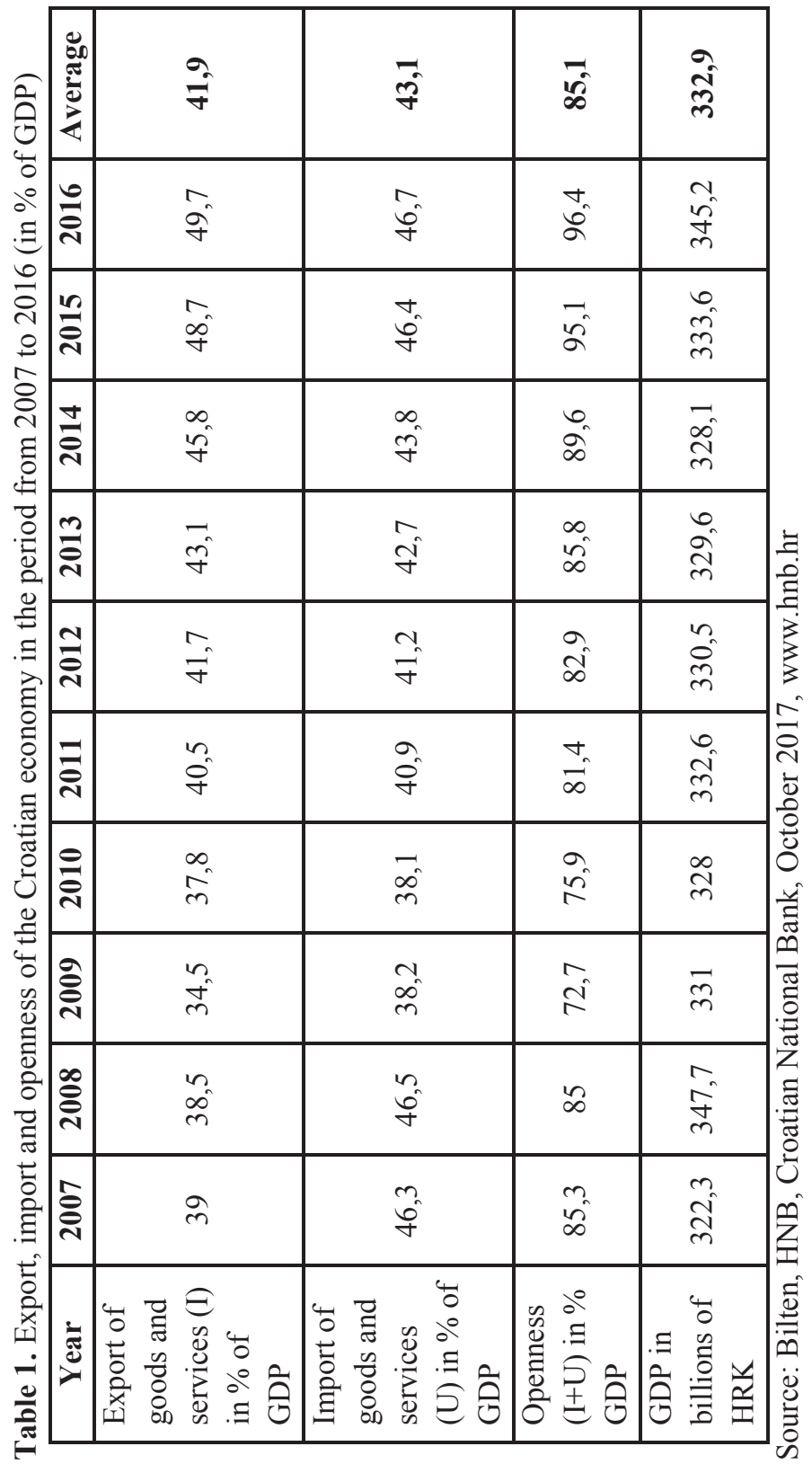


Innovativeness has long been seen as an important factor in increasing company exports and competitiveness on the international market. Export is seen as the first step towards internationalization in the broad sense (Jones, 2001). There are various ways to measure the export performance of companies. It can be divided into three different categories: 1. economic measures (e.g. export sales, profit and market share), 2. non-economic measures (e.g. number of export markets, new products exported or the contribution of export to product development) and 3. generic measures (e.g. export managers' degree of satisfaction with overall export performance, perceived export success or the degree to which export objectives have been fulfilled) (Katsikeas et al., 2000). There are several studies analysing the effects of innovation on export performance Lachenmaier and Wößmann (2006); Cassiman and Golovko (2011); Becker and Egger (2013), and there are also authors that analyse the effect of export (in terms of status or intensity) on innovation (Damijan et al., 2010; Kiriyama, 2012; Bratti and Felice, 2012). Despite the increasing number of empirical research papers attempting to bring the value of innovativeness closer and its relative impact on export intensity, there is no clear distinction between input and output indicators of innovativeness (D'Angelo, 2010). Günther and Norbert (1999) point out that the export related activities positively affect companies' innovativeness. Porter (2008) stated that companies, not nations, compete in international markets with industry being the basic analytical unit in understanding competitiveness. So, in order to assess the impact of innovation on export at the country level, the company-level impact of innovativeness needs to be analysed first. Many factors affect international trade, and innovation is considered one of the most important: innovation becomes the "added value" of the export product. Today innovation is considered to be one of the key factors of company's competitiveness. The key role of innovativeness was recognized by Porter, who claimed that companies gain the competitive edge thanks to innovative procedures (Porter, 2008). Caldera (2010) examines the relationship between innovativeness and the export behaviour of companies using data from Spanish firms. The results suggest a positive effect of innovativeness on the probability of participation in export markets. D'Angelo (2010) examined the influence of innovation measures on the export intensity of Italian small and mediumsized high-tech firms. The results revealed that "product innovations" and the "turnover derived from innovative activities" positively and significantly affect the export intensity of firms. Furthermore, the cooperation of high tech SMEs and universities as external partners in research and development has a positive impact on the company's export intensity. Cassiman and Golovko (2011), using a panel of Spanish manufacturing firms, showed that the strong positive association found between firm productivity and exports in the literature relates to the firm's earlier innovation decisions, and that, when controlling for product innovation, the relationship between productivity and exports 
vanishes for these innovating firms. Kiriyama (2012) highlights trade as one of the important factors that drive innovativeness. A firm's export status may improve its ability to introduce product innovations (learning by exporting), this idea was explored by Bratti and Felice (2012) using firm-level data on Italian manufacturing. They found that export status significantly increases the likelihood of introducing product innovations and that this effect is not fully captured by the channels such as larger markets (and, accordingly, firm size) or higher investments in R\&D. Karasek (2012) investigated if the innovation in small and medium-sized companies boosted their export potential. He established that low level of product innovation in Polish companies from the Lublin Voivodeship region negatively affected their propensity for export activities. Becker and Egger (2013) used survey data of German companies from the Leibniz Institute for Economic Research (Ifo) and found that companies that are active in product and process innovation are more likely to export than companies that are not. They also showed that product innovation has a bigger impact on exporting behaviour than process innovation. Damijan et al., (2010) tested the causal relationship between the innovation and export activities of Slovenian firms. Firm productivity and export decisions are closely related to innovation activity. Innovation may play a more important role in the decision to start exporting, and successful exporting may drive process innovation (Damijan, et al., 2010). The survey of manufacturing companies in Sweden shows that small companies' innovativeness is closely linked to participation in international trade and exports to the G7-countries (Andersson and Lööf, 2011). Germany traditionally relies on export-oriented industries that provide high quality products in technical areas, and high-quality production is largely based on incremental innovations. It is accepted that the level of innovation and competitiveness of national economies depends not only on the internal capacities of the company and the sector, but also on the national systems of innovation in the territorial and functional sense (Kaiser, 2015). The paper analyses the institutional foundation of innovation and competitiveness of two German industrial sectors: mechanical engineering and biotechnology. It applies a systematic innovation approach to determine which changes at the national and regional level explain why mechanical engineering has retained a competitive advantage for decades while biotechnology is undergoing a dynamic competitiveness reduction process (Kaiser, 2015).

On the sample of Greek manufacturing companies in 2010, the causal relationship between innovation and export of "young" and "adult" companies was investigated. The results did not support the existence of causality between innovation and export, but indicate that the cause of causality is different between "young" and "adult" companies. Equally, the indirect and direct impact of R \& D is confirmed as an indirect link between innovation and export (Gkypali et al., 2015). Navarro-García and Peris-Ortiz (2015) indicate that export-oriented entrepreneurship has a positive impact on 
export performance. Belderbos et al. (2015) examine the impact of innovation on export growth based on the Belgian CIS (Community Innovation Survey) for 2000, 2004 and 2006, which contains information on the value of export of innovative and non-innovative companies. The results emphasize that companies that are persistently innovating record the highest export intensity and value growth, as well as the significant impact of innovation on export. Companies that introduce product innovations also show a significant volume of export. Smaller companies are no less successful in accessing export markets outside the European Union. The findings suggest that policies promoting innovation are key to achieving export competitiveness (Belderbos et al., 2015). Boermans and Roelfsem (2015) explore the effect of internationalization on company's innovation and performance (growth in employment and sales growth), taking into account interdependencies among variables on a sample of 150 small Dutch companies participating in the Export Promotion Program. The main results show that internationalization has a positive impact on innovation. Internationalization increases company's success directly and indirectly through innovation, while the direct impact of innovation on the company's performance is insignificant. Hasanov et al. (2015) explore the link between innovation indicators and export results on a sample of unbalanced panel data for 48 Asian countries from 1997 to 2011. The findings have shown that only the indicator of the innovativeness of the number of country's registered industrial designs is positively correlated with export performance. It was established that other indicators of innovation are not significantly related with export performance in the country. Baldwin and Hanel (2015) have demonstrated a positive correlation between innovation and increased export activity or increased market share of Canadian processing industry. Massaro et al. (2017) explore how small and medium enterprises (SMEs) operating in Northern Italy and Slovenia used their innovative potential to expand business across the border while their home markets suffered from the great recession that started in 2007. The findings of the study showed that export performance is positively influenced by incremental innovation and risk preference and that there is a relationship between innovation and export performance (Massaro et al., 2017). Export market orientation as a strategic approach provides managers with specific skills and knowledge related to the foreign market and allows them to challenge innovative solutions for exports. Under conditions of high market dynamism and competitiveness, foreign customers' needs are constantly changing and emphasis should be placed on the offer of innovative products (Makri et al., 2017). Walheiser and Schwens (2017) investigated the relationship between exporters' innovativeness (i.e. their product innovation novelty and intensity) and new product performance and how this association is moderated by structural control mechanisms (i.e. centralization and formalization of the export function). The research was conducted on a sample of 136 German exporting firms. The results contributed to the 
theory explaining how structural control mechanisms intervene in the consistency of the relationship between exporters' innovativeness and new product performance. Based on survey data from 4347 East German firms, the study was conducted by Lejpras (2019) to explore the relationships among knowledge sourcing, innovativeness and export performance of a firm, and investigate how these links differ between service and manufacturing companies. The author found that both internal and external knowledge influence a firm's exports both directly path and indirectly via firm innovativeness (mediator variable). For service firms, external knowledge sourcing is more important for enhancing internal knowledge and innovativeness than for manufacturing companies (Lejpras, 2019).

\section{RESEARCH METHODS}

Based on the defined objective, the following hypothesis was tested: There is a positive relationship between innovativeness and export in Croatian companies. The research was conducted based on the survey method. In the hypothesis, innovativeness is an independent variable, and export is a dependent variable. To prove the hypothesis, Spearman rank correlation and the Kruskal-Wallis ANOVA test were used. Statistical testing is performed at a significance level of $95 \%(\alpha=0.05)$, (Šlogar, 2018). Statistical analysis and data analysis were carried out by STATISTICA 6.1 StatSoft inc. 1983-2003.

\subsection{Sample}

The basic set from which the sample was chosen consists of registered companies throughout the Republic of Croatia that were actively carrying out their activities in 2016. It is a three-stage stratified random sample that consists of 900 companies (Šlogar, 2018). For the first stratification level, the differential criterion is the division of counties according to three regions: 1. Northwestern Croatia 2. Central and Eastern (Panonian) Croatia and 3. Adriatic Croatia. For the second level of stratification, the differential criterion is the size of the company. The provisions of the Accounting Act (Official Gazette No. 58/07), which prescribe the conditions to be met by the company, are applied: the number of employees, the amount of revenue and the amount of total assets. For the third level of stratification, NKD 2007 (National Classification of Activities) categories are used, and the target companies belong to the following areas: $\mathrm{C}$ - Processing industry, Section 10-33 and J - Information and Communication, Section 62 - computer programming, consultancy and related activities (Šlogar, 2018). Data were collected on the export orientation of the companies for 2014 and 2015 and the market in 
which each individual company operates. The originally developed questionnaire was piloted and sent to 10 randomly selected companies from the defined database. The aim was to check the user-friendliness of individual claims from previous studies and to identify potential uncertainties regarding some of the questions. Subsequently, the questionnaire was modified and revised (Šlogar, 2018). To measure the innovativeness, the scale adapted from Nybbak (2012) was used which consists of 15 items and assesses the sub-factors of product innovation, process innovativeness and business system innovativeness. Additionally, a 5-point Likert scale was used: 1 - 'the claim does not even refer to my company' to 5 - 'the claim is completely related to my company'.

\subsection{Data collection}

The research was conducted over the last three months of 2016. In the process of data collection, an e-mail was sent to 900 Croatian companies that were actively doing business on the domestic or international market, selected from the online database, www.biznet.hr, i.e. from the Register of Business Entities of the Croatian Chamber of Commerce and the Croatian Exporters Register of the Croatian Chamber of Commerce. The questionnaires were sent in October 2016 to the e-mail addresses of CEOs and executive managers of companies that are included in the sample. A reminder and another questionnaire was sent in November to those who had not yet responded. Within the first three months, 303 out of 900 questionnaires had been properly filled out and sent back, resulting in a response rate of $35.31 \%$ (Šlogar, 2018). Of a total of 345 collected questionnaires, only 303 were used in the final analysis; the rest, those with significant amounts of data missing, were excluded. It should be noted that a huge number of leading Croatian companies returned completed questionnaires.

\section{RESEARCH RESULTS}

The results show that the largest number of companies falls under The National Classification of Territorial Units for Statistics, NKPJS, 52.1\%, are from Northwestern Croatia (HR01); 33\% are located in Central and Eastern (Pannonian) Croatia (HR02); and the smallest number of companies, 14.7\%, are located in Adriatic Croatia (HR03). The distribution of companies throughout the industrial sector shows that the largest number of companies, $22 \%$, is engaged in the production of metals and metal products, machinery and equipment; $18 \%$ in the production and processing of wood, pulp and paper; $17 \%$ in the production of chemical products, synthetic fibres, rubber, mineral products; $16 \%$ in the production of food, beverages and tobacco products; $11 \%$ in financial and other 
services; $9 \%$ in the production of textiles and textile products; and $7 \%$ in computer programming. The results show that in $2015,44.6 \%$ of the surveyed companies generated revenue of less than HRK 60 million, 28\% between HRK 60 million and 300 million, and $27.4 \%$ of the companies generated revenue of more than HRK 300 million. The results show that in 2015 , the total assets of $44.6 \%$ of the surveyed companies were less than HRK 30 million, $27.7 \%$ from HRK 30 million to 150 million and $27.7 \%$ more than HRK 150 million. Furthermore, the results show that in the previous three years, the observed companies sold $42.2 \%$, of products on the international market, $32.1 \%$ on the national market and $25.7 \%$ on the regional market. The results show that of the exported products most are finished products $-79.5 \%$, and the rest are made up of roughly equal amounts of semi-finished products, $10.6 \%$, and services, $9.9 \%$. As part of the empirical research, it was attempted to determine whether there is a positive relationship between innovativeness and exports. To test the hypothesis, Kruskal-Wallis ANOVA test and Spearman correlation were used. The relationship between innovativeness and export of products was tested in 2014 and 2015. The results are shown in Table 2. 


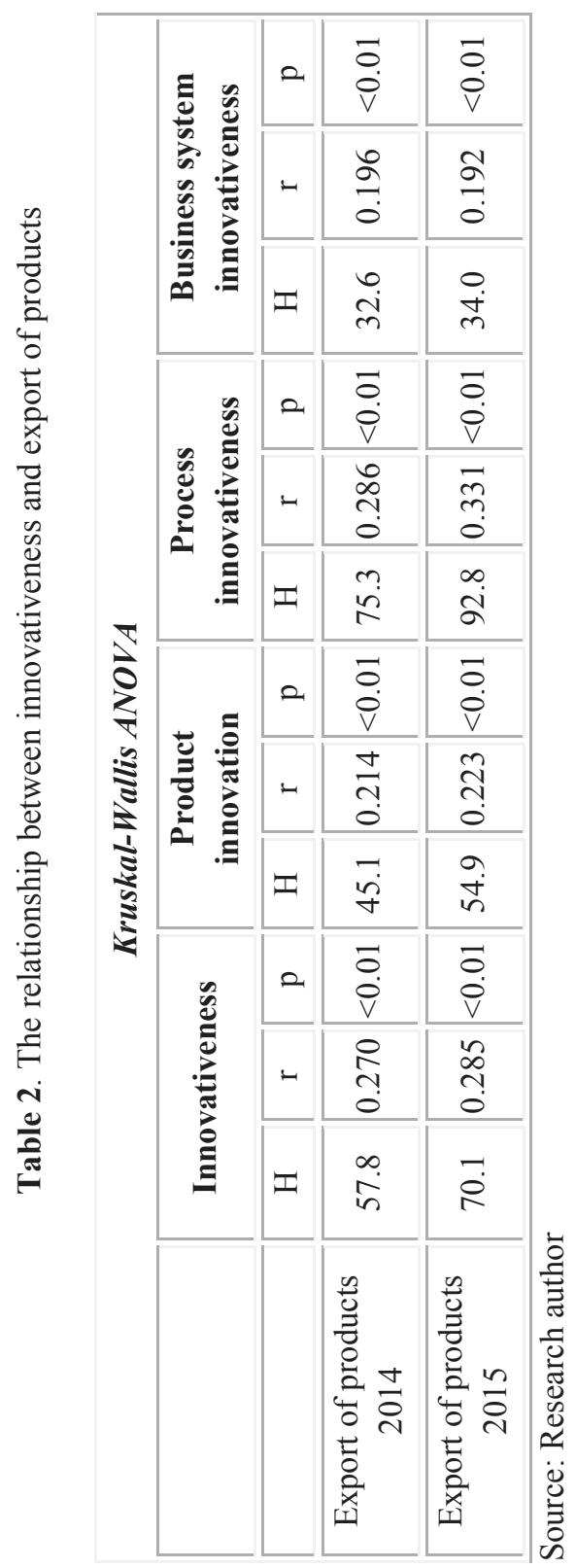


Table 2 shows the results of the Kruskal-Wallis ANOVA test and Spearman rank correlation coefficients. These results demonstrate that there is a statistically significant positive relationship between all dimensions of innovativeness and product exports $(\mathrm{p}$ $<0.01$ ). The share of total company revenue in 2014 achieved by exports shows there is a statistically significant positive association with innovativeness: product innovation, process innovativeness and business system innovativeness. That is, the growth of the share of total company revenue in 2014 is expected to grow in all dimensions of innovativeness. The export of products in 2014 shows a statistically significant positive association with innovativeness, product innovation, process and business systems innovativeness. Also, product exports in 2015 are statistically significantly positively related to product innovativeness, process innovativeness and business system innovativeness, that is, an increase in exports from year to year is expected to result in the growth of all dimensions of innovativeness. The results of the canonical analysis are presented below in Table 3 and Figure 1.

Table 3. Canonical analysis of the relationship between innovativeness and exports

Canonical Analysis Summary: Canonical R: 0,354, Chi2(9)=45,851 p<0,0001

\begin{tabular}{|c|c|c|}
\hline Number of questions & 3 & 3 \\
\hline 1. & Export of products 2014 & Product innovativeness \\
\hline 2. & Export of products 2015 & Process innovativeness \\
\hline 3. & Export 2015 (\%) & $\begin{array}{c}\text { Business system } \\
\text { innovativeness }\end{array}$ \\
\hline
\end{tabular}

Source: Research author

Canonical correlation coefficient ( $\mathrm{R}$ Canonical) is 0.354 , which is a positive relationship, a statistical significance was tested using a Chi-square test $\left(\mathrm{Chi}^{2}\right)$ that shows a statistically significant correlation $(\mathrm{p}<0.0001)$.

Figure 1 illustrates the canonical analysis showing a statistically significant positive relationship between exports and innovativeness. These results fully confirmed the hypothesis. 
Figure 1. Canonical analysis of relationship between innovativeness and exports

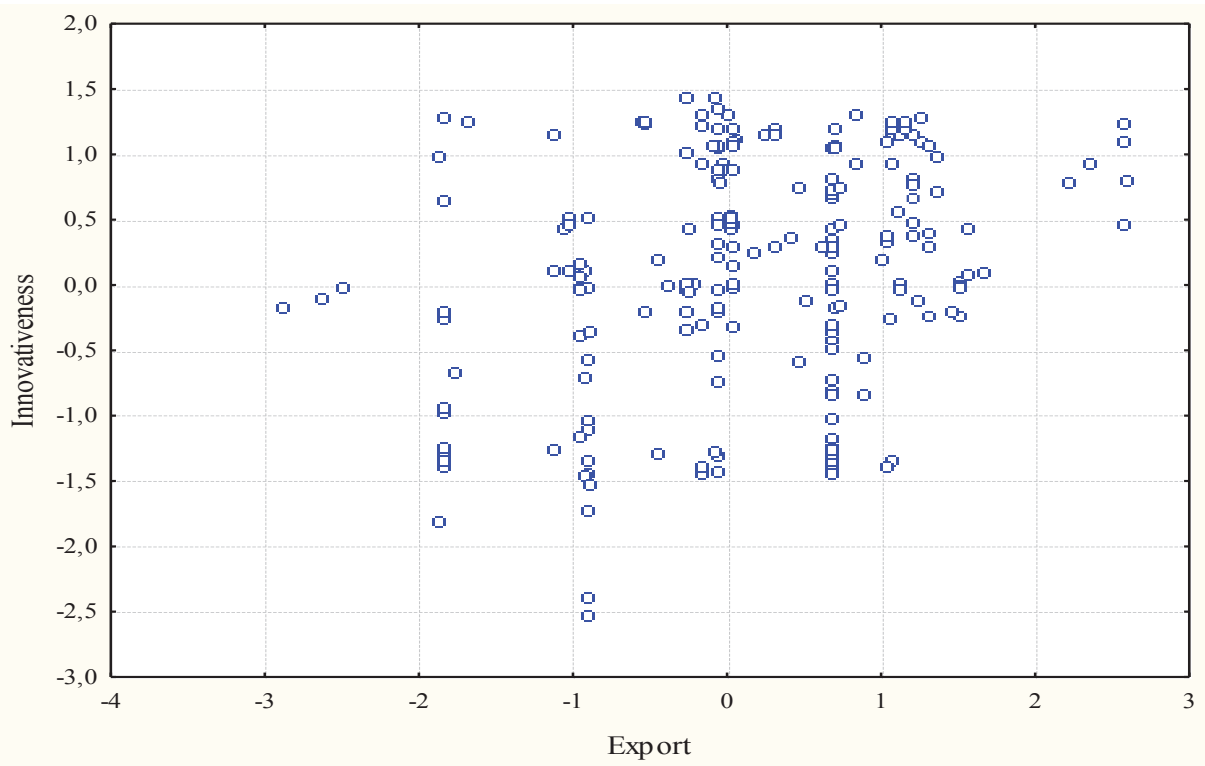

Source: Research author

\section{CONCLUSIONS}

In countries with a small market, like Croatia, companies are dependent on the international environment and economic conditions on the world market. Under conditions of a demanding and complex business environment, investments in innovative products and boosting export activities are considered to be important factors that can increase the efficiency, employment growth and competitiveness of a company. For this purpose, an extensive research of previous studies was carried out in order to understand the relationship of innovativeness and exports as a whole, from the standpoint of different economies, different activities, innovations and export performance. Statistical results confirm the primary research question and hypothesis that innovativeness is positively related to the export of Croatian companies. There are limitations of this research because it can be established that the long period of crisis in the Republic of Croatia contributed to the weak business performance of companies on both the domestic and international markets. It is believed that such a business environment had an influence on the answers given by the respondents in the questionnaire. Although the selection is based on the 
principle of impartiality in sample making, such a sample does not meet the principle of representativeness at the same time, so the results of this research may only be considered relevant for companies in the $\mathrm{C}$ and J NKD 2007 sectors that are involved in the research and cannot be generalized for all companies. In conceptual terms, the contribution is manifested in the development of scientific thinking about the existence of a positive link between innovativeness and exports. The scientific contribution is also reflected in the fact that research was carried out in the Republic of Croatia where such research is lacking. Additionally, the research should contribute to results that will be of practical benefit to companies, the new findings may help in the planning of participation on international markets. Similarly, the results of empirical research should be an incentive for similar scientific research in the future. The companies can further increase exports performance by responding to specific customer demands and learning from foreign competitors. In future research, empirical testing should be conducted on a larger sample and other types of business should be included. In the light of future research along this particular subject, it would be most fruitful to replicate this study in different industrial or cultural environments because extending research to other characteristics, such as leadership style, tenure and heterogeneity, may further advance the findings of this study. This also suggests that there might be other mediators or moderators that influence the product innovation and export but were not hypothesized in this study. Further research should be conducted to verify and explain the phenomenon. It can be concluded that companies should be encouraged to develop innovativeness for which they require a proactive approach and use of all available resources to actively search for business opportunities in order to increase their export to the international market.

\section{REFERENCES:}

1. Andersson, M. and Lööf, H. (2011), Small business innovation: firm level evidence from Sweden, The Journal of Technology Transfer, October , Volume 37, Issue 5, pp. 732-754, Springer US.

2. Atkinson, R. D. i Ezell, S. J. (2014), Ekonomika inovacija - Utrka za globalnu prednost. Zagreb, Mate d.o.o.

3. Baldwin, J. R. and Hanel, P. (2015), Innovation and Knowledge Creation in an Open Economy Canadian Industry and International Implications, Cambridge University Press, (eBook), ISBN: 9780511510847.

4. Becker, S.O. and Egger, P. H. ( 2013), Endogenous product versus process innovation and a firm's propensity to export, Empirical Economics, 
February, Volume 44, Issue 1, pp. 329-354 (doi: 10.1007/s00181-009-0322$6)$.

5. Belderbos, R., Duvivier, F. and Wynen, J., (2015), Innovation and Export Competitiveness: Evidence from Flemish Firms, Working Paper Steunpunt Ondernemen en Internationaal Ondernemen (STOIO), September.

6. Bilten, HNB, listopad 2017., http://www.hnb.hr

7. Boermans, M. A. and Roelfsema, H. (2015), Small firm internationalization, innovation, and growth, International Economics and Economic Policy, DOI 10.1007/s10368-014-0310-y, Springer-Verlag Berlin Heidelberg, Vol. 13. Iss. 2, 283- 296.

8. Bratti, M. and Felice, G., (2012), Are Exporters More Likely to Introduce Product Innovations? The World Economy, November, Volume 35, Issue 11, pp. 1559-1598 https://doi.org/10.1111/j.1467-9701.2012.01453.x.

9. Caldera, A. (2010), Innovation and exporting: evidence from Spanish manufacturing firms, Review of World Economics (Weltwirtschaftliches Archiv), Springer;Institut für Weltwirtschaft (Kiel Institute for the World Economy), December, Vol. 146(4), pp. 657-689, DOI: 10.1007/s10290-0100065-7.

10. Calantone, R. J., Cavusgil, S. T. and Zhao, Y. (2002), Learning orientation, firm innovation capability and firm performance, Industrial Marketing Management 31, 515-524.

11. Cassiman, B. and Golovko, E., (2011), Innovation and Internationalization through exports, Journal of International Business Studies, January, Volume 42, Issue 1, pp. 56-75.

12. D'Angelo, A. (2010), Innovation and export performance: a study of Italian high-tech SMEs, Journal of Management \& Governance, Volume 16, Issue 3, pp. 393-423, DOI 10.1007/s10997-010-9157-y, Springer Science+Business Media, LLC.

13. Damijan, J. P., Kostevc, Č., and Polanec, S. (2010), From Innovation to Exporting or Vice Versa? The World Economy, Vol. 33, Issue 3, 374-398.

14. Gkypali, A., Rafailidis, A. and Tsekouras, K. (2015), Innovation and export performance: do young and mature innovative firms differ?, Eurasia Business and Economics Society, 5:397-415DOI 10.1007/s40821-015-0030-4, Springer.

15. Günther, E. and Norbert, J. (1999), Export and Innovation Activities in the German Service Sector: Empirical Evidence at the Firm Level, October 28. ZEW Discussion Paper No., 99-53. Available at SRN: https://ssrn.com/abstract=376220 or http://dx.doi.org/10.2139/ssrn.37622 0 . 
16. Hasanov, Z., Abada, O. and Aktamov, S. (2015), Impact of innovativeness of the country on export performance: evidence from Asian countries, IOSR Journal of Business and Management, (IOSR-JBM) e-ISSN: 2278-487X, pISSN: 2319-7668, Volume 17, Issue 1.Ver. III Jan.

17. Hirsch, S. and Bijaoui, I. (1985), R\&D Intensity and Export Performance: A Micro View, Weltwirtschaftliches Archiv, Vol. 121, Iss. 2, June, 238- 251.

18. Hoq, M. Z. and Che Ha, N. (2009), Innovativeness: Its Antecedents and Relationship to SME Business Performance, ANZMAC.

19. Hult, G. T. M., Hurley, R. F. and Knight, G. A. (2004), Innovativeness: Its antecedents and impact on business performance, Industrial Marketing Management, Vol. 33, Iss.5, July, 429-438.

20. Hurley, R. F. and Hult, T. G. M. (1998), Innovation, Market Orientation, and Organizational Learning: An Integration and Empirical Examination, Journal of Marketing, Vol. 62, July, 42-54.

21. Jones, M. V., (2001), First steps in internationalisation: concepts and evidence from a sample of small high technology firms, Journal of International Management, 7 (3), pp. 191-210. (doi:10.1016/S1075-4253(01)00044-8).

22. Kaiser, R. (2015), The institutional foundation of innovativeness and competitiveness of two German industries: biotechnology and mechanical engineering compared, Econ Change Restruct DOI 10.1007/s10644-015-91773, Springer Science + Business Media New York, November.

23. Karasek, A. (2012), Innovation and export performance: evidence from Lublin Voivodeship, Make Learn, Management, Knowledge and Learning, International Conference.

24. Katsikeas, C.S., Leonidou, L.C. and Morgan, N. A., (2000), Firm-level export performance assessment: review, evaluation, and development, Journal of the Academy of Marketing Science, Vol. 28, Issue 4, 2000, pp. 493-511. https://doi.org/10.1177/0092070300284003.

25. Kiriyama, N. (2012), Trade and Innovation: Synthesis Report, OECD Trade Policy Papers, No. 135, OECD Publishing, Paris. http://dx.doi.org/10.1787/5k9gwprtbtxn-en.

26. Lachenmaier, S. and Wößmann, L. (2006), Does innovation cause exports? Evidence from exogenous innovation impulses and obstacles using German micro data, Oxford Economic Papers, Volume 58, Issue 2, pp. 317-350. https://doi.org/10.1093/oep/gpi043.

27. Lazibat, T. i Kolaković, M. (2004), Međunarodno poslovanje u uvjetima globalizacije, Zagreb, Sinergija nakladništvo d.o.o. 
28. Lejpras, A. (2019), Determinants of export performance: differences between service and manufacturing SMEs, Service Business, Springer;Pan-Pacific Business Association, Vol. 13(1), March, pp. 171-198.

29. Makri, K. , Theodosiou, M. and Katsikea, E. (2017), An empirical investigation of the antecedents and performance outcomes of export innovativeness, International Business Review, Volume 26, No. 4, pp. 628-639 DOI: 10.1016/j.ibusrev.2016.12.004.

30. Massaro, M., Rubens, A., Bardy and R. Bagnoli, C. (2017), Antecedents to export performance and how Italian and Slovenian SMEs innovate during times of crisis, Journal of Eastern European and Central Asian Research, DOI: http://dx.doi.org/10.15549/jeecar.v4i1.153 Vol.4, No.1, pp. 1-22.

31. National Classification of Activities NKD 2007(Official Gazette No. 58/07).

32. Navarro-García, A. and Peris-Ortiz, M. (2015), Export Entrepreneurship and Export Performance. A Resource and Competitive Perspective International Publishing Switzerland, Peris-Ortiz, M., Sahut, J.-M. (eds.), New Challenges in Entrepreneurship and Finance, ISBN 978-3-319-08888-4 (eBook), DOI 10.1007/978-3-319-08888-4, Springer International Publishing Switzerland.

33. Nybakk, E. (2012), Learning orientation, innovativeness and financial performance in traditional manufacturing firms: a higher-order structural equation model, International Journal of Innovation Management, 16 (5), 28.

34. Porter, M. E. (2008), Konkurentska prednost, Postizanje i održavanje vrhunskog poslovanja, Zagreb, Masmedia.

35. Ruepitiviriya, O. and Puttawong, D. (2018), The effects of entrepreneurial orientation and innovativeness on export performance of small and medium enterprises in Thailand, RMUTSB Academic Journal, Humanities and Social Sciences, Vol 3 No 2, July - December, pp. 129-138.

36. Schumpeter, J. A. (1934), The theory of economic development, English edition, Cambridge, Mass, Harvard University Press.

37. Šlogar, H. (2018), Procjena inovativnosti s aspekta poduzetničke orijentacije, tržišne orijentacije i orijentacije na učenje, doktorski rad, Sveučilište u Rijeci, Ekonomski fakultet.

38. Šlogar, H., Šokčević, S., Jerin K. (2018): Utjecaj poduzetničke orijentacije na poslovanje poduzeća, Fourth International Scientific-Business Conference LIMEN 2018 Leadership \& Management:Integrated Politics of Research and Innovations, December 13, Belgrade, Serbia, 103-110. DOI: https://doi.org/10.31410/limen.2018.103

39. The Accounting Act (Official Gazette No. 78/15). 
40. The National Classification of Territorial Units for Statistics (NKPJS) from 2007 (Official Gazette, Official Gazette no. 35/2007).

41. Van de Vrande, V., De Jong, J.P.J., Vanhaverbeke, W. and De Rochemont, M. (2009). Open innovation in SMEs: Trends, motives and management challenges. Technovation 29, 423-437.

42. Wakelin, K. (1998), Innovation and export behaviour at the firm level, Research Policy, Volume 26, Issues 7-8, April 1998, pp. 829-841 https://doi.org/10.1016/S0048-7333(97)00051-6.

43. Walheiser, D. and Schwens,C. (2017), Exporters' Innovativeness and New Product Performance: Organizational Structure as a Moderator, Academy of Management Proceedings, , No.1

44. www.biznet.hr

45. http://www.worldbank.org 


\title{
ODNOS IZMEĐU INOVATIVNOSTI I IZVOZA U HRVATSKIM PODUZEĆIMA
}

\author{
Helena Šlogar \& Heri Bezić
}

\section{Sažetak}

Svrha je ovog rada ispitati odnos inovativnosti i izvoza u hrvatskim poduzećima. U istraživanju su sudjelovala 303 hrvatska izvozna poduzeća iz prerađivačke industrije te informacijske i komunikacijske tehnologije. Istraživanje je provedeno metodom anketiranja u zadnjem tromjesečju 2016. godine. U tu svrhu korištena je Spearman rang korelacija, test Kruskal-Wallis ANOVA i kanonska analiza. Rezultati pokazuju da postoji pozitivan odnos između inovativnosti i izvoza u hrvatskim poduzećima. Rezultati nude teorijske i upravljačke implikacije. Ovo istraživanje ima praktične implikacije za hrvatska poduzeća da povećaju svoju učinkovitost i inovativnost. Vrijednost se ogleda u odnosu inovativnosti i izvoza te postoji važan istraživački prostor za znanstvenike u literaturi o međunarodnoj trgovini, poduzetništvu i upravljanju. U kontekstu ovog istraživanja, vjerojatno je da inovativnost utječe na izvozne aktivnosti poduzeća, što se može pozitivno odraziti na stvaranje i održavanje njihove konkurentske prednosti na međunarodnom tržištu.

Ključne riječi: inovativnost, inovativnost proizvoda, inovativnost procesa, inovativnost poslovnog sustava, izvoz, hrvatska poduzeća. 